OAK RIDGE

NATIONAL LABORATORY

MANAGED BY UT-BATTELLE

FOR THE DEPARTMENT OF ENERGY

\title{
Thermal and Chemical Stability of Baseline and Improved Crystalline Silicotitanate
}

\section{Decenber 2001}

Prepared by

P. A. Taylor

C. H. Mattus 


\title{
DOCUMENT AVAILABILITY
}

Reports produced after January 1, 1996, are generally available free via the U.S. Department of Energy (DOE) Information Bridge.

\section{Web site http://www.osti.gov/bridge}

Reports produced before January 1, 1996, may be purchased by members of the public from the following source.

\author{
National Technical Information Service \\ 5285 Port Royal Road \\ Springfield, VA 22161 \\ Telephone 703-605-6000 (I-800-553-6847) \\ TDD 703-487-4639 \\ Fax 703-605-6900 \\ E-mail omfp@mtos/fedwpr:d/apv \\ Web site http://www.ntis.gov/support/ordemowabout.htm
}

Reports are available to DOE employees, DOE contractors, Energy Technology Data Exchange (ETDE) representatives, and International Nuclear Information System (NIS) representatives from the following source.

Office of Scientific and Technical Information

P.O. Box 62

Oak Ridge, TN 37831

Telephone 865-576-8401

Fax 865-576-5728

E-mail reports@adonis.osti.gov

Web site http://www.osti.gov/contact.html

This report was prepared as an account of work sponsored by an agency of the United States Government. Neither the United States government nor any agency thereof, nor any of their employees, makes any warranty, express or implied, or assumes any legal liability or responsibility for the accuracy, completeness, or usefulness of any information, apparatus, product, or process disclosed, or represents that its use would not infringe privately owned rights. Reference herein to any specific commercial product, process, or service by trade name, trademark, manufacturer, or otherwise, does not necessarily constitute or imply its endorsement, recommendation, or favoring by the United States Government or any agency thereof. The views and opinions of authors expressed herein do not necessarily state or reflect those of the United States Government or any agency thereof. 
Nuclear Science and Technology Division

THERMAL AND CHEMICAL STABILITY OF BASELINE AND IMPROVED CRYSTALLINE SILICOTITANATE

P. A. Taylor

C. H. Mattus

Date Published: December 2001

\author{
Prepared by \\ OAK RIDGE NATIONAL LABORATORY \\ P.O. Box 2008 \\ Oak Ridge, Tennessee 3783 1-6285 \\ managed by \\ UT-BATTELLE, LLC \\ for the \\ U.S. DEPARTMENT OF ENERGY \\ under contract DE-AC05-00OR22725
}





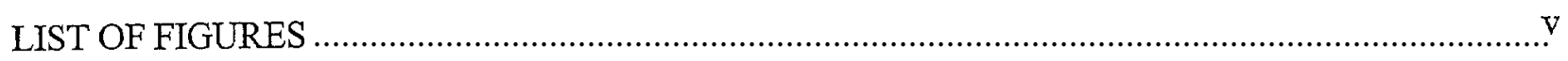

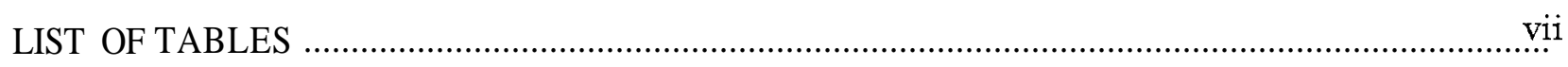

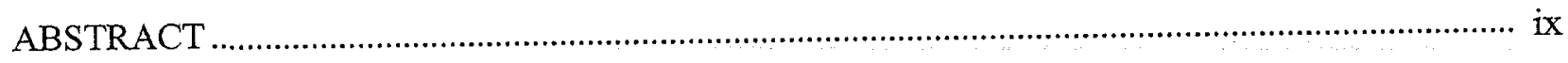

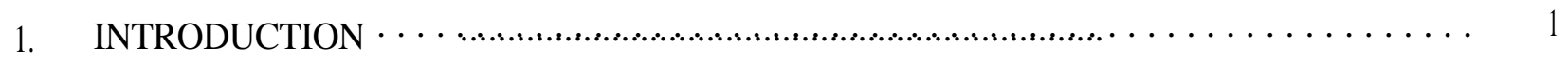

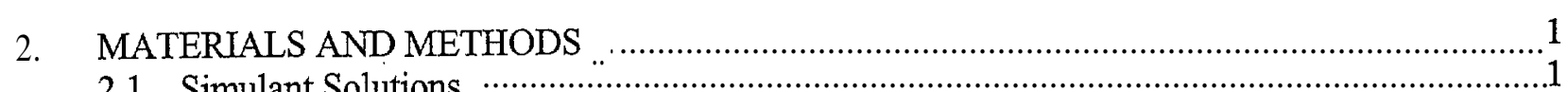

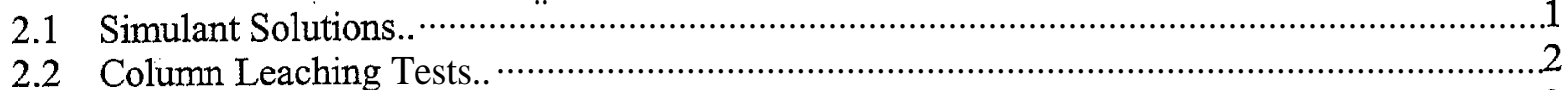

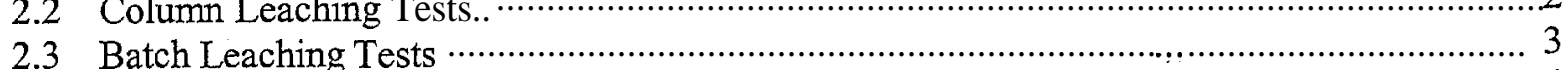

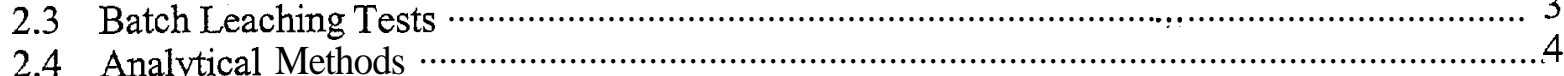

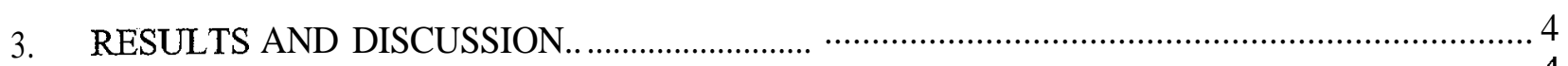

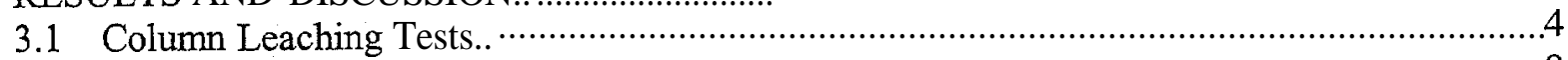

3.2 Once-Through Column Test ........................................................................................ 9

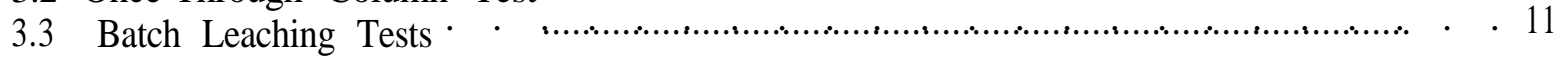

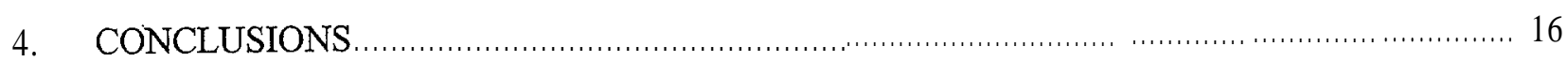

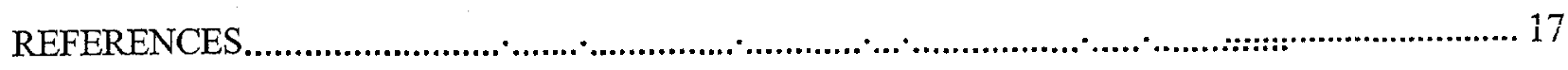





\section{LIST OF FIGURES}

Figure

Page

1 Column leaching test equipment....... 3

2 Operational data for column leaching tests using baseline (9090-76) and improved (MH-9098-9) CST.

3 Metal concentrations in the recirculating simulant from the column leaching test using baseline (9090-76) CST.

4 Metal concentrations in the recirculating simulant from the column leaching test using improved (MH-9098-g) CST .......

5 Aluminum concentrations in CST samples from column leaching test using baseline (9090-76) and improved (MH-9098-9) CST

6 Cesium loading results for CST samples from the column leaching tests...... 8

7 Measured and adjusted cesium capacity for CST samples taken from the top of the baseline column

8 Aluminum concentrations in feed and effluent samples from the once-through column test using improved (MH-9098-9) CST.

9 Aluminum concentration in simulant samples from batch leaching tests using baseline and improved granular CST and CST powder.......

10 Niobium concentration in simulant samples from batch leaching tests using baseline and improved granular CST and CST powder.

11 Aluminum concentration in CST samples from batch leaching tests using baseline and improved granular CST and CST powder

12 Results of cesium loading tests for CST samples from batch leaching tests stored in SRS average simulant at $23^{\circ} \mathrm{C}$..........

13 Results of cesium loading tests for CST samples from batch leaching tests stored in SRS average simulant at $80^{\circ} \mathrm{C}$

14 Results of cesium loading tests for CST samples after 4 months of storage in SRS average simulant 



\section{LIST OF TABLES}

Table

Page

1 Composition of SRS average supernate simulant ....................................................

2 Aluminum concentration and measured and adjusted cesium loading capacity for CST samples from the once-through column test ......................................................

3 Average cesium loading capacities for CST samples stored at 23 and $80^{\circ} \mathrm{C}$ for up to

6 months 



\section{ABSTRACT}

The Savannah River Site (SRS) has been evaluating technologies for removing radioactive cesium $\left({ }^{137} \mathrm{Cs}\right)$ from the supemate solutions stored in the high-level waste tanks at the site. Crystalline silicotitanate (CST) sorbent (IONSTV IE-911@, UOP LLC, Des Plaines, IL), which is very effective at removing cesium from high-salt solutions, was one of three technologies that were tested. Because of the extremely high inventory of ${ }^{137} \mathrm{Cs}$ expected for the large columns of CST that would be used for treating the SRS supemate, any loss of flow or cooling to the columns could result in high temperatures from radiolytic heating. Also, even under normal operating conditions, the CST would be exposed to the supernates for up to a year before being removed. Small-scale batch and column tests conducted last year using samples of production batches of CST showed potential problems with CST clumping and loss of cesium capacity after extended contact with the simulant solutions. Similar tests-using samples of a baseline and improved granular CST and the CST powder used to make both granular samples-were performed this year to compare the performance of the improved CST.

The column tests, which used recirculating supemate simulant, showed that the baseline CST generated more precipitates of sodium aluminosilicate than the improved CST. The precipitates were particularly evident in the tubing that carried the simulant solution to and from the column, but the baseline CST also showed higher concentrations of aluminum on the CST than were observed for the improved CST. Recirculating the simulant through just a section of the tubing (no contact with CST) also produced small amounts of precipitate, similar to the amounts seen for the improved CST column. The sodium aluminosilicate formed bridges between the CST granules, causing clumps of CST to form in the column. Clumps were visible in the baseline CST column after 1 month of operation and in the improved CST column after 2 months, For the baseline CST column, the clumps were routinely dispersed by backwashing the column with simulant. After 96 days of operation, a thin hard layer of CST formed on the bottom screen of the baseline column that restricted flow through the column. The bottom cap was removed and the CST was scraped from the screen to restore the column to normal operation. After 3 months of operation, the improved CST column was completely clumped together and could not be dispersed by backwashing. The pressure drop through the column was still relatively low, so the test was continued until the pressure drop increased to $>15$ psig after 105 days of operation. The column was then disassembled, and the CST was physically removed from the column and broken up. These results show that both the baseline and improved CST, when contacted with the supemate simulant, have the potential for forming clumps that can restrict the flow through the small columns used in these tests.

The cesium capacity of the CST samples from the column tests with recirculating simulant decreased slightly as the run time increased. Most of this decrease could be attributed to the weight of cancrinite (a sodium aluminosilicate) on the CST samples. Tests conducted last year using production batch samples of CST showed a more pronounced drop in cesium capacity under comparable conditions.

A column test using the improved CST and once-through simulant showed few problems during 5 months of operation. The pressure drop through the column remained low; however, when the final samples were taken after 5 months of operations, the CST in the column had clumped together. The final sample taken from the top $1 \mathrm{~cm}$ of the column showed a $65 \%$ drop in cesium capacity compared with all the other samples from this column. This sample also contained the highest concentration of cancrinite, but the weight of cancrinite could account for only a small fraction of the drop in cesium capacity by simple dilution of the CST.

The CST in the batch tests stored at elevated temperatures in average simulant formed clumps, but this occurred at a slower rate than that observed last year during comparable tests using production batch 
samples of CST. Storage at elevated temperatures caused a gradual decrease in cesium capacity as the storage time increased, with a loss in capacity of up to $20 \%$ after 5 to 6 months at $80{ }^{\circ} \mathrm{C}$. The results for the baseline and improved CST samples were essentially the same for these batch tests. 


\section{INTRODUCTION}

The Savannah River Site (SRS) has evaluated technologies for removing ${ }^{137} \mathrm{Cs}$ from the supemate solutions stored in high-level waste tanks at the site. IONSIV IE-911 $\mathbb{B}$ (UOP, LLC, Des Plains, IL), an inorganic crystalline silicotitanate (CST) ion-exchange material with a high affinity for cesium, is the key material in one of the processes that was tested. Results obtained from work conducted at ORNL in $1999^{1}$ showed that higher temperatures $(50$ to 120 "C) could cause desorption of previously loaded cesium from CST in simulant solutions and that the CST would not reload the cesium when the temperature was reduced following 60 days of contact at the higher temperatures. Because of the extremely high inventory of ${ }^{137} \mathrm{Cs}$ that would be expected for the large columns of CST that would be used for treating the SRS supemate, any loss of flow or cooling to the columns could result in high temperatures within the column from radiolytic heating.

Previous long-term batch and flow-through leaching tests using samples from production batches of IONSIV IE-9 11 showed potential problems with clumping of the CST particles. ${ }^{2}$ Work at other DOE labs has shown that niobium and silicon leach from the $\mathrm{CST}^{3,4}$ and that aluminosilicates precipitate from the SRS simulants onto the CST particles. ${ }^{5}$ UOP has supplied pre-production samples of an improved IE-91 1 product that was treated to reduce the amount of leachable niobium and silicon. Batch and flowthrough leaching tests, similar to the earlier tests, were conducted to determine the performance of this new material.

\section{MATERIALS AND METHODS}

Two samples of granular CST, and the CST powder used to prepare them were received from UOP in November 2000 and January 2001 . The first IE-9 11 sample is a baseline material (labeled as 9090-76) that was prepared using the same process as the commercial. CST available from UOP but with a higher level of documentation and quality control. The second IE-9 11 sample (designated as Improved or MH-9098-g) was treated to remove most of the leachable material (mainly niobium) from the CST. The IE-9 10 CST powder sample, which was used to make, both of the granular CST samples, was designated as 30950-48. Batch leaching tests with all three samples were completed, and column leaching tests were performed using the two granular samples. The baseline CST was pretreated by pumping $3 \mathrm{MNaOH}$ through a column of the CST for $24 \mathrm{~h}(10 \mathrm{~L} \mathrm{NaOH}$ for $400 \mathrm{~g} \mathrm{CST})$ and then backwashing with deionized water to remove any fines prior to use. The MH-9098-9 and 30950-48 samples were used as received for the batch tests., The MH-9098-9 sample used in the column tests was pretreated with recirculating $1.9 M \mathrm{NaOH}$ for $24 \mathrm{~h}$ to ensure that the alkalinity of the CST had stabilized prior to starting the tests.

\subsection{Simulaqt Solutions}

The average supemate simulant was prepared at ORNL using a recipe supplied by SRS ${ }^{6}$ The composition of this simulant is shown in Table 1. The simulant was prepared in 20-L batches, without any cesium. A portion of each batch was then spiked with $50 \mathrm{mg} / \mathrm{L}$ cesium (added as $\mathrm{CsCl}$ ) and $1 \mu \mathrm{Ci} / \mathrm{L}$ ${ }^{137} \mathrm{Cs}$ for use in the cesium loading tests. Each large batch of simulant was analyzed for metals by inductively coupled plasma-emission spectroscopy (ICP-ES) and for anions by ion chromatography. The spiked batches of simulant were analyzed for cesium by ICP-mass spectroscopy (ICP-MS) and for ${ }^{137} \mathrm{Cs}$ by gamma counting at the ORNL Radioactive Materials Analysis Laboratory. 
Table 1. Composition of SRS average supernate simulant

\begin{tabular}{cc}
\hline Comuonent & Concentration $(M)$ \\
\hline $\mathrm{Na}^{+}$ & 5.6 \\
$\mathrm{~K}^{+}$ & 0.015 \\
$\mathrm{OH}^{-}$ & 1.91 \\
$\mathrm{NO}_{3}{ }^{-}$ & 2.14 \\
$\mathrm{NO}_{2}$ & 0.52 \\
$\mathrm{AlO}_{2}$ & 0.31 \\
$\mathrm{CO}_{3}{ }^{2-}$ & 0.16 \\
$\mathrm{SO}_{4}{ }^{2-}$ & 0.15 \\
$\mathrm{Cl}^{-}$ & 0.025 \\
$\mathrm{~F}^{-}$ & 0.032 \\
$\mathrm{PO}_{4}{ }^{3-}$ & 0.010 \\
$\mathrm{C}_{2} \mathrm{O}_{4}{ }^{2-}$ & 0.008 \\
$\mathrm{SiO}_{3}{ }^{2-}$ & 0.004 \\
$\mathrm{MoO}_{4}{ }^{2-}$ & 0.0002 \\
\hline
\end{tabular}

\subsection{Column Leaching Tests}

Cesium-free average supernate simulant was recirculated through small polyvinyl chloride columns (1.6-cm ID by $120 \mathrm{~cm}$ tall) containing pretreated granular CST at room temperature. The columns were initially filled with $200 \mathrm{~g}$ of the CST, which gave a bed height of $90 \mathrm{~cm}$. The flow rate of each solution was $6 \mathrm{~mL} / \mathrm{min}$. The solutions were pumped through $0.45-\mu \mathrm{m}$-pore-size filter cartridges before entering each column, using a dual-head peristaltic pump and silicon rubber tubing. Figure 1 shows a photograph of the columns, pump, and filters. Pressure gauges on the inlet of the filters were used to monitor column plugging. Samples of the solutions were analyzed periodically for dissolved metals in order to measure CST leaching and precipitation of simulant components. The solutions were replaced when their concentrations changed significantly ( $>10 \%$ change or $200 \mathrm{mg} / \mathrm{L}$, whichever was larger). Samples of the CST were removed from the top and bottom of the columns each month and tested for cesium sorption and elemental composition. The baseline (9090-76) CST column was started on December 5, 2000, and ran for 6 months, and the improved CST (MH-9098-g) column was started on January 18, 2001, and ran for 5 months.

A slightly taller column $($ CST bed height $=115 \mathrm{~cm})$ of the same diameter was tested using the improved CST and average simulant in a once-through flow mode. The purpose of this test was to determine if continuous exposure of the CST to fresh simulant would result in the collection of higher amounts of precipitated aluminosilicate in the column. The flow rate for this column was $2.0 \mathrm{~mL} / \mathrm{min}$, giving a fluid residence time within the CST bed of about $1 \mathrm{~h}$ (which is about the same as was planned for a full-scale SRS column). Because the leaching and precipitation reactions have very slow kinetics, it was important to match the residence time for the full-scale columns, even though this meant that the fluid velocity would be lower. This test, which was started on February 3,200 1, ran for 5 months. 


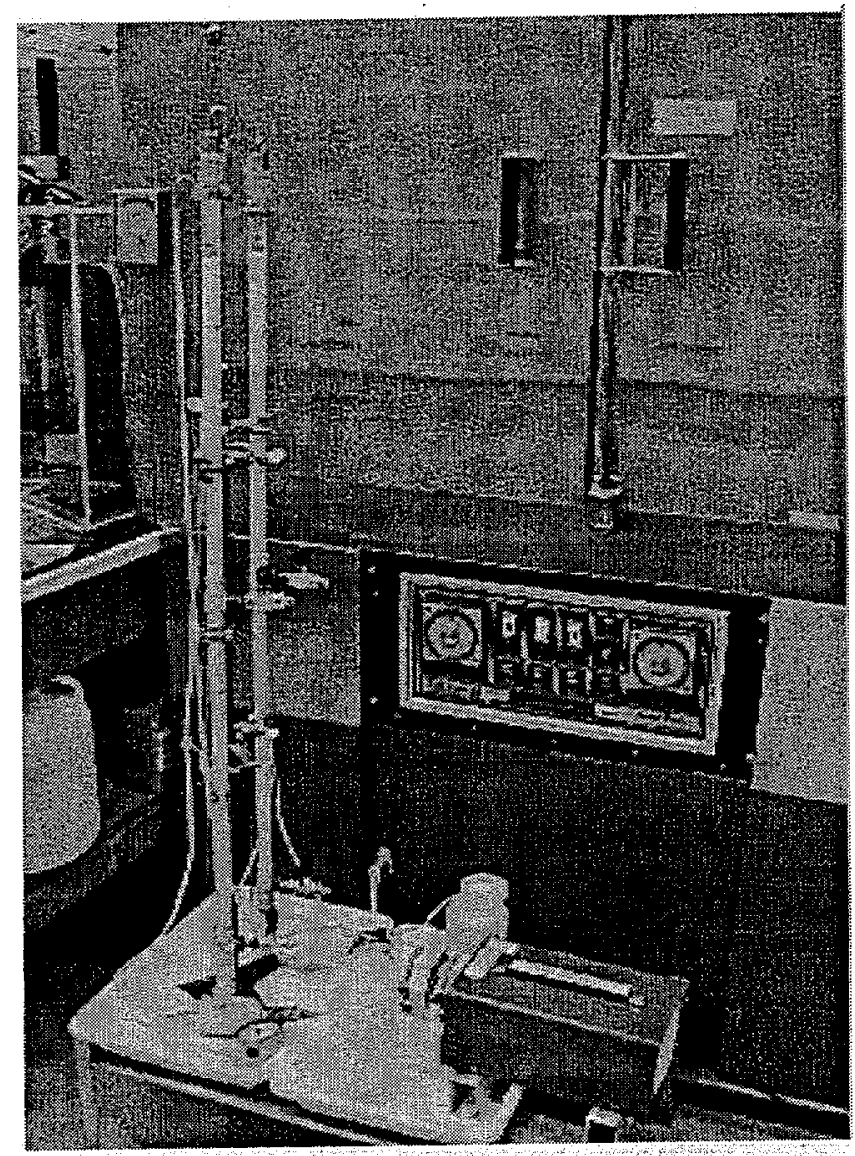

Fig. 1. Column leaching test equipment.

\subsection{Batch Leaching Tests}

Long-term batch leaching tests were conducted using a cesium-free average simulant to determine the effects of temperature on the stability of the CST. Teflon bottles containing $16 \mathrm{~g}$ of CST and $240 \mathrm{~mL}$ of simulant were stored at room temperature and $30,35,50$, and $80^{\circ} \mathrm{C}$. The temperatures up to $35^{\circ} \mathrm{C}$ represent possible normal operating temperatures while the higher temperatures would represent upset conditions. Samples of the solutions were analyzed each month for dissolved metals in order to measure CST leaching and/or precipitation of simulant components. Previous experience had shown that the bottles stored at $80^{\circ} \mathrm{C}$ would lose about $1 \mathrm{~g} /$ month of water by evaporation. These bottles were weighed initially and then weighed again prior to taking samples, and deionized water was added to-replace the water that had evaporated. After removing the samples, the bottles were weighed to get a new initial weight for the next sampling period. Samples of the CST were removed each month and tested for cesium sorption and elemental composition. The baseline (9090-76) granular CST and CST powder (30950-48) tests were started on December 5, 2000, and the improved CST (MH-9098-9) tests were started on January 17, 2001. 


\subsection{Analytical Methods}

The CST samples from the leaching tests were rinsed three times with a small volume of deionized water and then dried at room temperature in a desiccator prior to analysis. Samples of unused CST were contacted with the simulant solution for $10 \mathrm{~min}$ and then rinsed and dried following the same procedure used for the batch and column leaching tests. These samples served as the baseline (zero time) for comparing all analytical results for the leaching test samples. Three subsamples from each group of leaching-test CST samples were dried to a constant weight at $105^{\circ} \mathrm{C}$ to determine the amount of moisture in the CST and then heated at $400^{\circ} \mathrm{C}$ for $4 \mathrm{~h}$ (per SRS procedure) to obtain a consistent weight that could be used for calculating glass formulations at the Defense Waste Processing Facility. The average weight loss for the granular CST samples was $3.9 \mathrm{wt} \%$ at $105^{\circ} \mathrm{C}$ and $13.5 \mathrm{wt} \%$ at $400^{\circ} \mathrm{C}$, and the CST powder showed losses of $3.0 \mathrm{wt} \%$ and $11.8 \mathrm{wt} \%$ at $105^{\circ} \mathrm{C}$ and $400^{\circ} \mathrm{C}$, respectively. These weight loss results were used to calculate cesium loadings on a dry-weight basis. The cesium loading tests used an SRS average simulant containing $50 \mathrm{mg} / \mathrm{L}$ cesium and about $1 \mu \mathrm{Ci} / \mathrm{L}{ }^{137} \mathrm{Cs}$. The CST samples and simulant were contacted in Teflon flasks for 7 days at room temperature $\left(21\right.$ to $\left.23^{\circ} \mathrm{C}\right)$. Simulant samples were collected and filtered $(0.2-\mu \mathrm{m}$ pore size $)$ and then gamma counted on a Cobra II counter with a sodium iodide detector (Packard Instrument Co., Downers Grove, II).

The inductively coupled plasma (ICP) analyses were performed using a model 61E Trace ICP from Thermo Jarrell Ash following standard EPA method SW846-6010B. Standard reference samples from the National Institute of Standards and Technology (NIST) were analyzed along with the test samples to verify the accuracy of the results. The NIST standard was analyzed 11 times, once for each batch of CST samples, and the coefficient of variation (mean/standard deviation) was 3 to $4 \%$ for $\mathrm{Al}, \mathrm{Na}, \mathrm{Si}$ and $\mathrm{Ti}$. Both simulant solutions and CST samples were digested using nitric and'hydrofluoric acids in a microwave oven to solubilize the materials; boric acid was then added to complex the fluoride ion prior to analysis.

\section{RESULTS AND DISCUSSION}

\subsection{Column Leaching Tests}

During the first 3 months of operation for the column with the baseline (9090-76) CST, there was a continual buildup of an aluminosilicate precipitate on the inside of the silicon rubber tubing leading to and from the column. The precipitate restricted flow through the tubing and caused the back pressure in the column to increase. The tubing was replaced seven times during this period, resulting in a reduction in the back pressure each time. By comparison, the tubing for the column using the improved (MH-9098-9) CST did not show any precipitate formation until after 2 months of operation, at which point the tubing was replaced one time. A control test was performed by recirculating the average simulant through a section of the silicon rubber tubing without any contact with CST. Small amounts of precipitate were visible after 8 weeks of operation in quantities similar to those observed in the tubing for the improved CST column. The pressures and flow rates for both columns during the first 110 days of operation are shown in Fig. 2. The baseline CST column contained several weak agglomerations of CST after 1 month of operation. Backwashing the column after each sampling campaign helped break up the clumps of CST.

After 3 months of operation, the back pressure for the column with the baseline CST started to increase, without any visible buildup of precipitate in the lines. Backwashing the column did not reduce the 


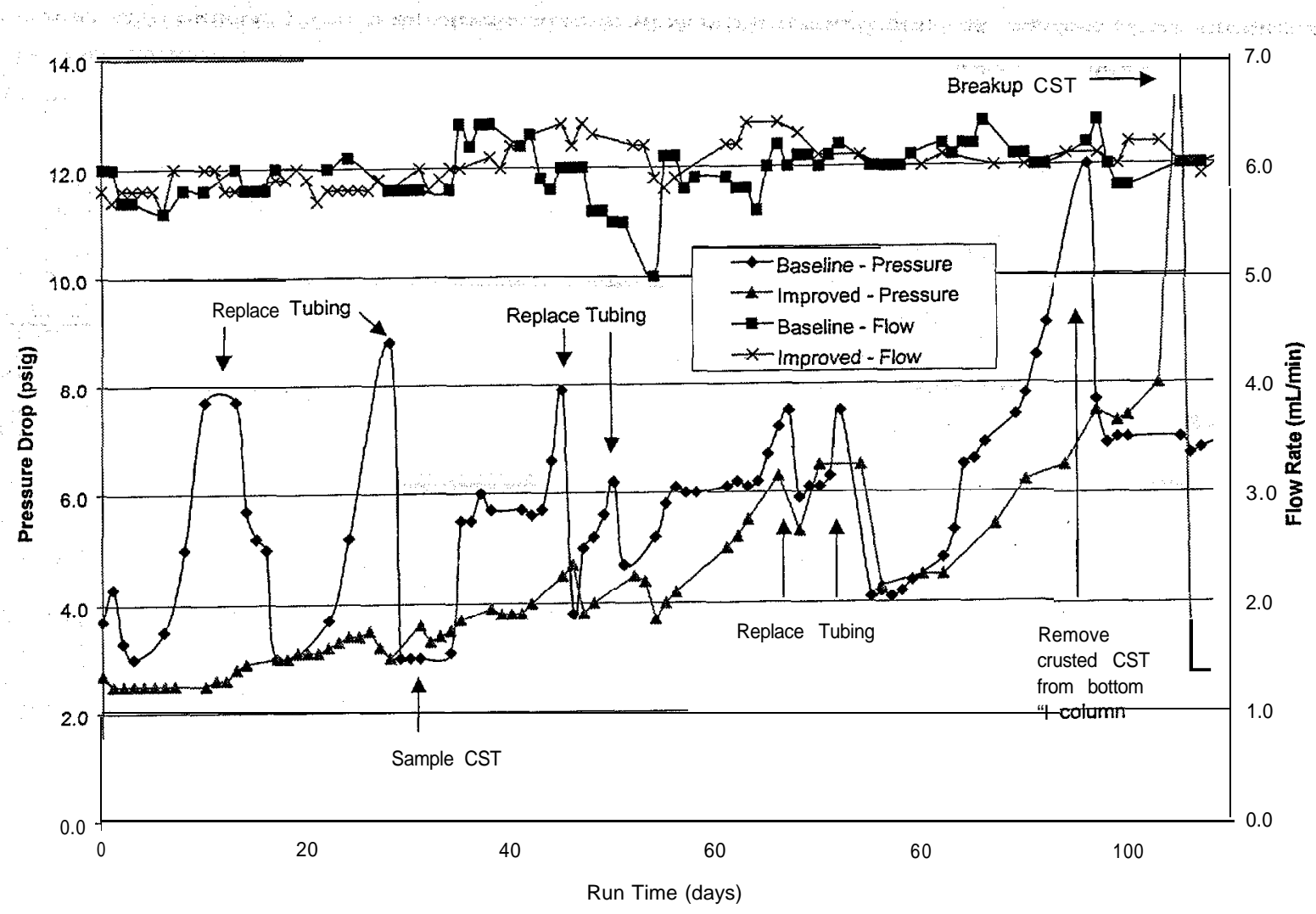

Fig. 2. Operational data for column leaching tests using baseline (9090-76) and improved (MH-9098-9) CST.

pressure, even after all the visible clumps of CST had broken up. The back pressure increased to 12 psig after 96 days of operation. The column was then inverted, and the bottom cap was removed. A thin layer (about $0.5 \mathrm{~cm}$ ) of crusty CST was stuck to the bottom screen of the column. After removing this CST layer and placing the column back in operation, the back pressure was reduced and stayed in a range of 5 to 7 psig for the remainder of the test. Only very small amounts of precipitate collected in the tubing for this column during the final 3 months of operation.

For the column using the improved (MH-9098-g) CST, no precipitate was visible in the tubing during the first month of operation, but small amounts started to collect during the second month. The amount of precipitate that did collect in the tubing was much less than that collected in the tubing for the column using the baseline CST. The pressure drop for this column stayed quite low (2.5 to $5 \mathrm{psig}$ ) during the first 2 months of operation, although a slow, steady increase was observed during this time. After 66 days of operation, the pressure drop had increased to $6.3 \mathrm{psig}$, and significant amounts of white precipitate were visible in the tubing leading to and from the column. After replacing the tubing, the back pressure dropped back to 4.3 psig. There was no further buildup of precipitate in the lines for this column.

After almost 2 months of operation, there were only a few weak clumps of CST visible in the top portion of the column using the improved CST. When the column was backwashed after almost 3 months of operation, the entire bed of CST was clumped together and could not be moved, even after shaking the column. The back pressure through the column was still relatively low (5.5 to $7.5 \mathrm{psig}$ ), and the column continued to operate normally, even with the CST clumped together. After 105 days of operation, the back pressure increased to over 15 psig and the flow through the column almost stopped. Both end caps 
of the column were removed, and a thin metal rod was used to break up the bed of CST and remove it from the column. The CST was lightly cemented together throughout the column. The column was then reassembled and backwashed to remove the tines generated by breaking up the bed of CST. The column operated normally for the remainder of the test.

The ICP results for dissolved $\mathrm{Al}, \mathrm{Si}$, and $\mathrm{Nb}$ in the recirculating simulant solutions are shown in Figs. 3 and 4. There was much less variation in the metals concentrations of the simulant solutions for these tests than was observed last year during similar tests using production batch samples of CST. Initially there was no niobium in the simulant solutions, but the concentration increased quickly as niobium was leached from the CST into solution. The simulant from the baseline CST column showed higher niobium concentrations than the simulant fi-om the improved CST column. There was also a decrease in the aluminum and niobium concentrations in the simulant for both columns after 18 to 20 weeks of operation.

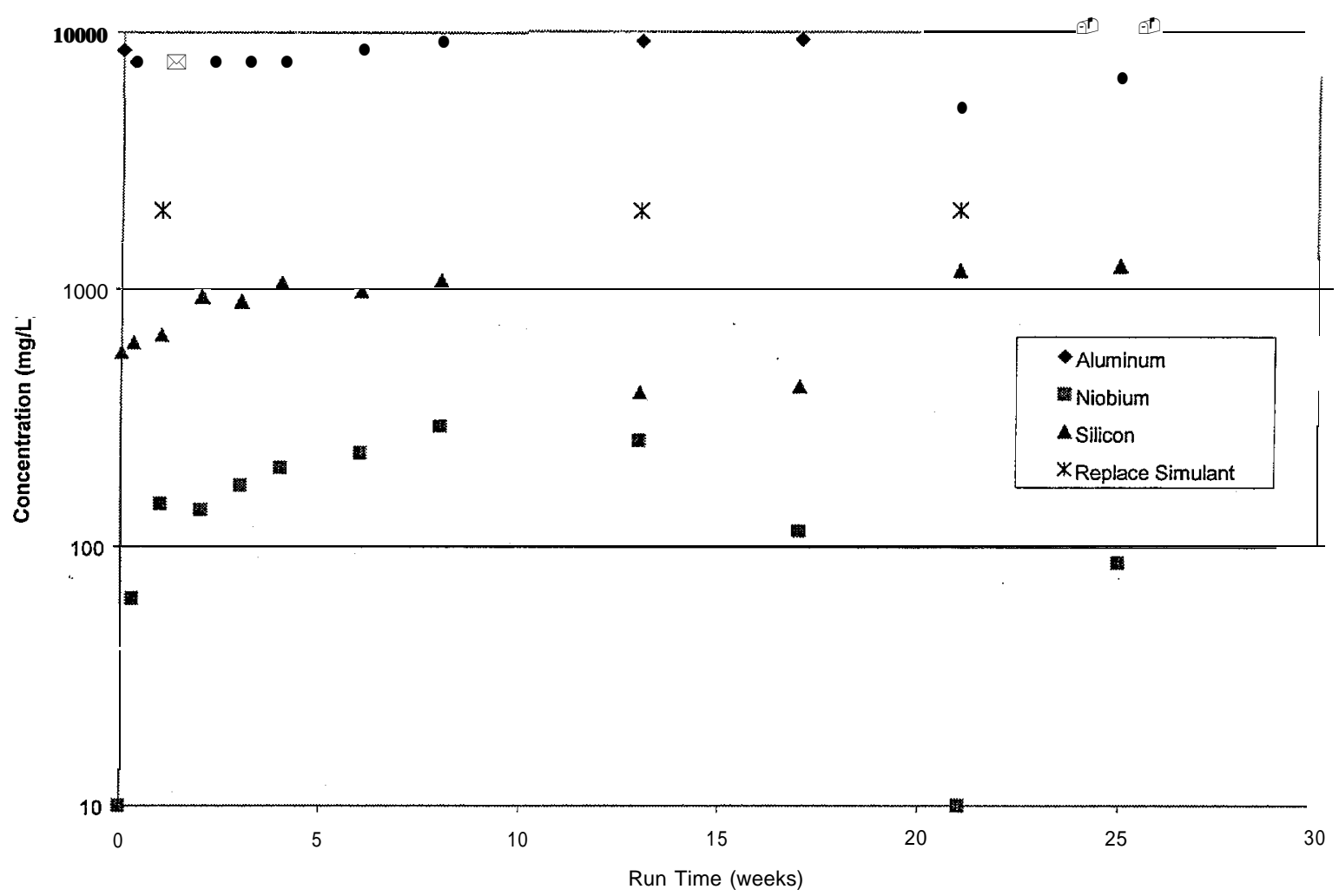

Fig. 3. Metal concentrations in the recirculating simulant from the column leaching test using baseline (9090-76) CST. 


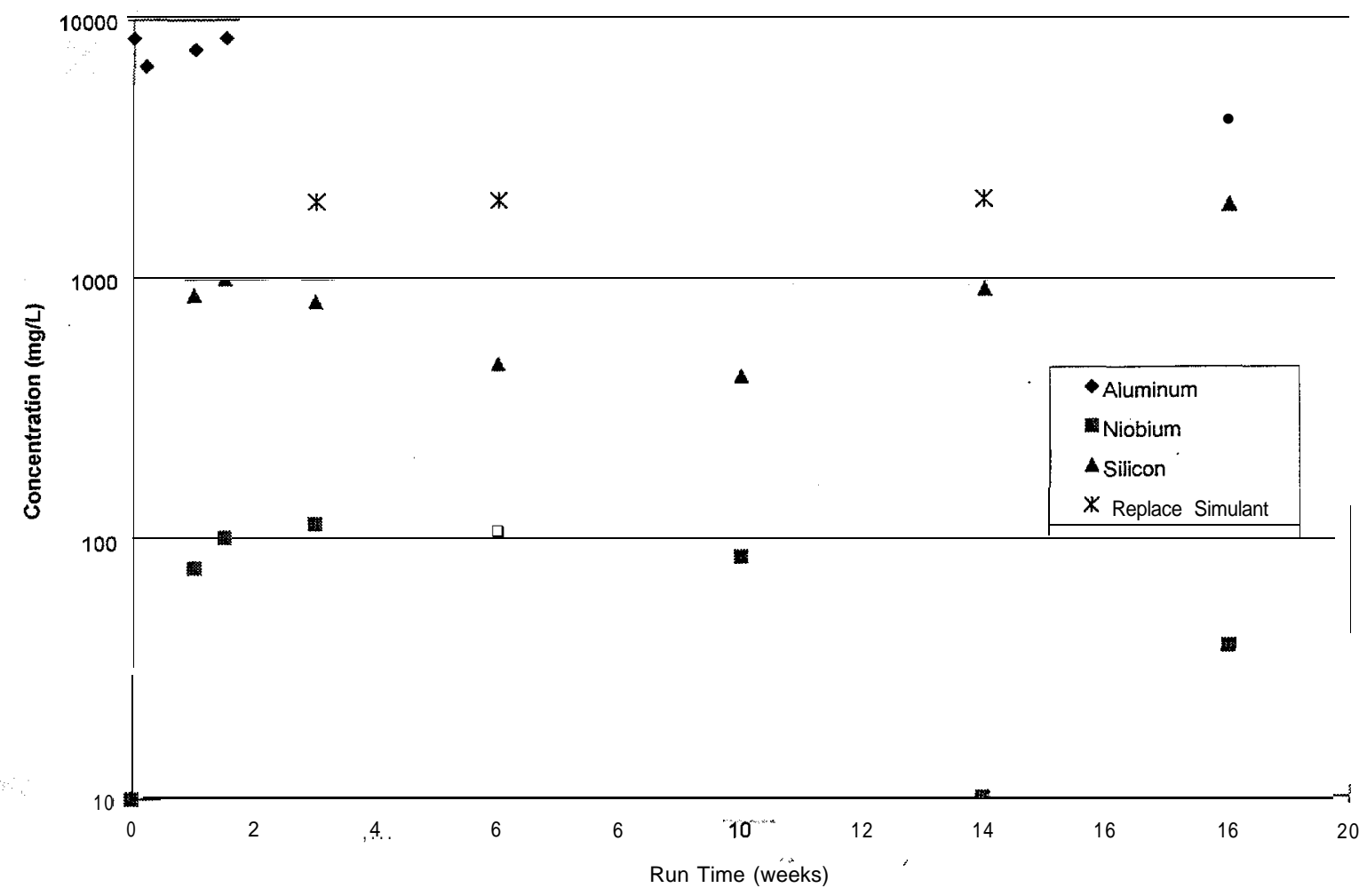

Fig. 4. Metal concentrations in the recirculating simulant from the column leaching test using improved (MH-9098-9) CST.

Slow increases were noted in the aluminum concentrations of the CST samples from both columns, particularly for the samples taken from the top of the bed (Fig. 5). Work at Sandia National Laboratories ${ }^{7}$ indicated that cancrinite, $\mathrm{Na}_{8} \mathrm{Al}_{6} \mathrm{Si}_{6} \mathrm{O}_{24}\left(\mathrm{NO}_{3}\right)_{2} \cdot 4 \mathrm{H}_{2} \mathrm{O}$, forms on the CST particles during storage in SRS simulant solutions. The variation in aluminum concentrations between the top and bottom CST samples . was much more pronounced for the column using the baseline CST. No other metal contaminants were detected in significant concentrations, and the concentrations of the CST components ( $\mathrm{Na}, \mathrm{Si}, \mathrm{Ti}, \mathrm{Zr}$, and $\mathrm{Nb}$ ) decreased very slightly as the aluminum concentration increased.

The cesium loading results for the CST samples from the column leaching tests are summarized in Fig. 6. There was a slight decrease in the cesium capacities of the samples from both columns as the run time increased, but the change was much smaller than that measured during similar tests conducted last year using production batch samples of CST. The "Reference" results are for unused samples of baseline (9090-76) CST that were analyzed with each batch of leaching test samples. These results showed good repeatability, which indicates that the loading tests were consistent, with a very small decrease measured for the 5- and 6-month tests. Generally there was only a small difference between the cesium capacities of the top and bottom samples from each column. The column with the improved (MH-9098-9) CST showed an increasing difference between the top and bottom samples after 3 and 4 months of run time. When the column plugged and the CST was removed from the column, the CST was mixed as it was reloaded, so the difference between the top and bottom samples disappeared for the 5-month samples. 


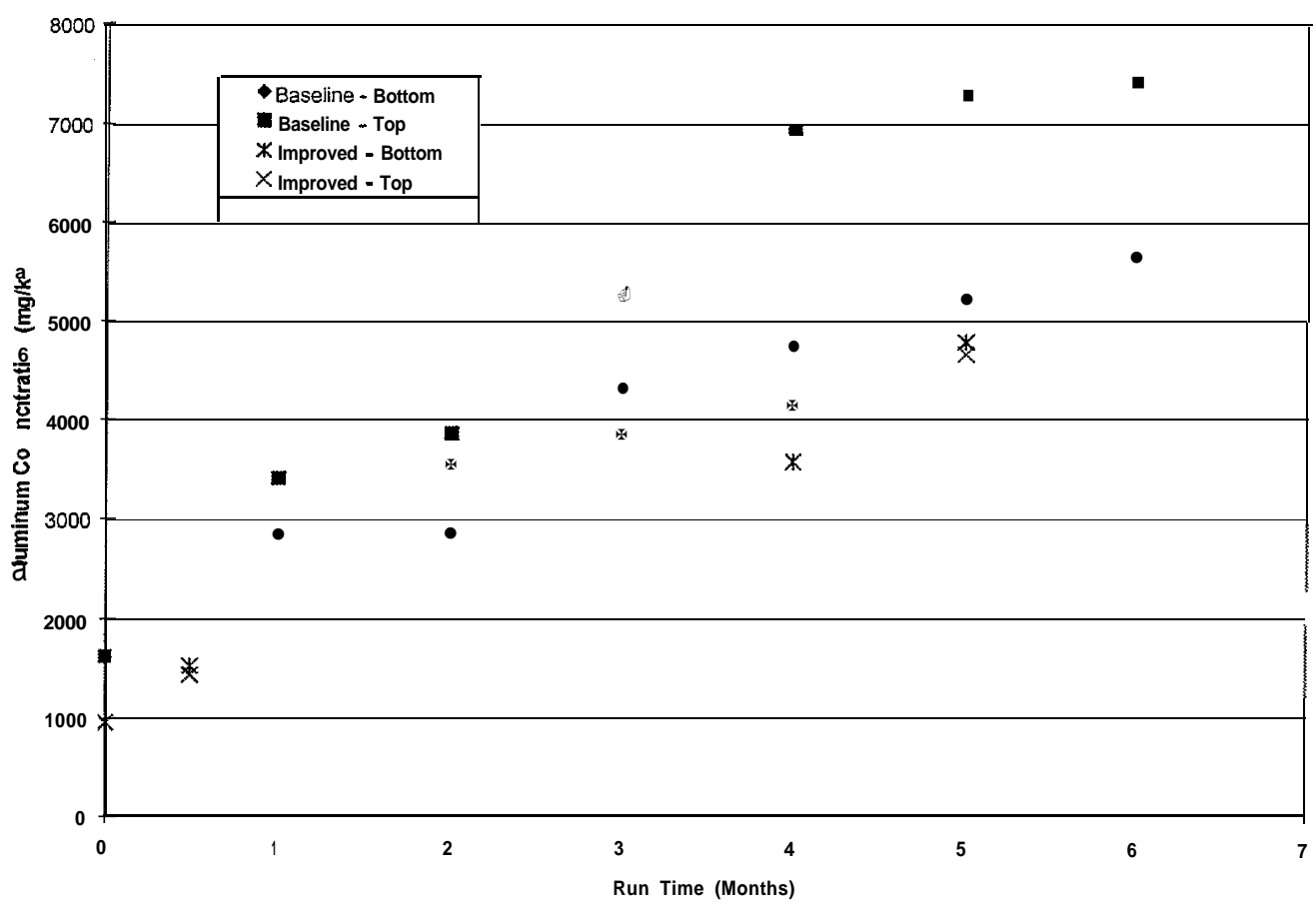

Fig. 5. Aluminum concentrations in CST samples from column leaching test using baseline (9090-76) and improved (MH-9098-9) CST.

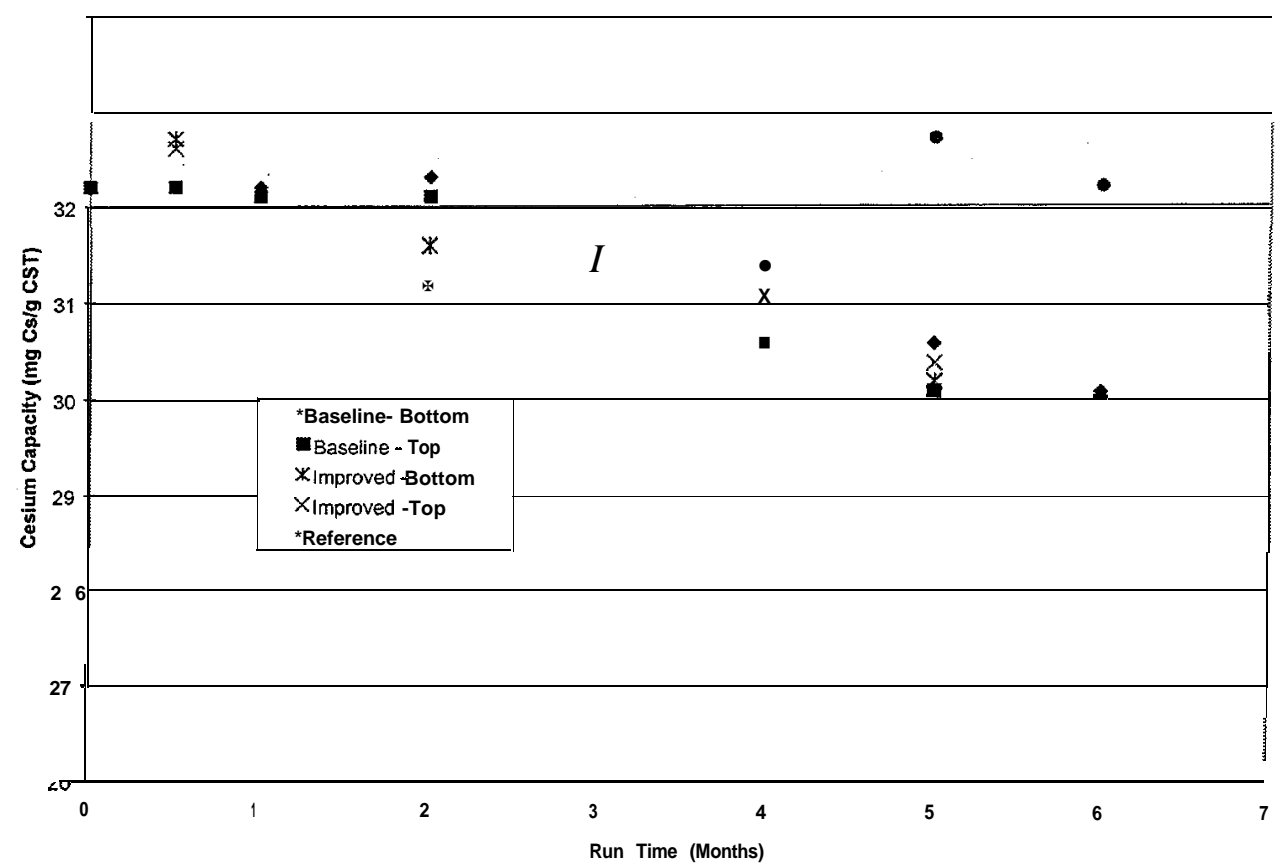

Fig. 6. Cesium loading results for CST samples from the column leaching tests. 
The buildup of cancrinite on the CST would reduce the actual amount of CST in the samples used for the cesium loading tests. By comparing the concentrations of aluminum and titanium in the CST samples, the ratio of CST to cancrinite can be calculated. Cancrinite is 14.8 wt \% Al, E-910 CST contains 19.9 wt \% Ti, and IE-911 contains 17.8 wt \% Ti. These ratios can be used to calculate an adjusted cesium loading, using only the weight of CST in each sample. The adjusted results for the samples taken from the top of the baseline CST column are shown in Fig. 7. Dilution of the CST by cancrinite accounted for most of the loss in cesium capacity. There was a slight decrease in the adjusted cesium capacity for the CST samples taken after 5 and 6 months of column operation, but the Reference sample (unused baseline CST) showed a similar trend. These results indicate that the decrease in cesium capacity was caused by some variation in the loading tests, rather than a change in the CST for the last two tests. The samples taken from the bottom of the baseline> CST column and both sets of samples from the column with the improved CST showed similar results.

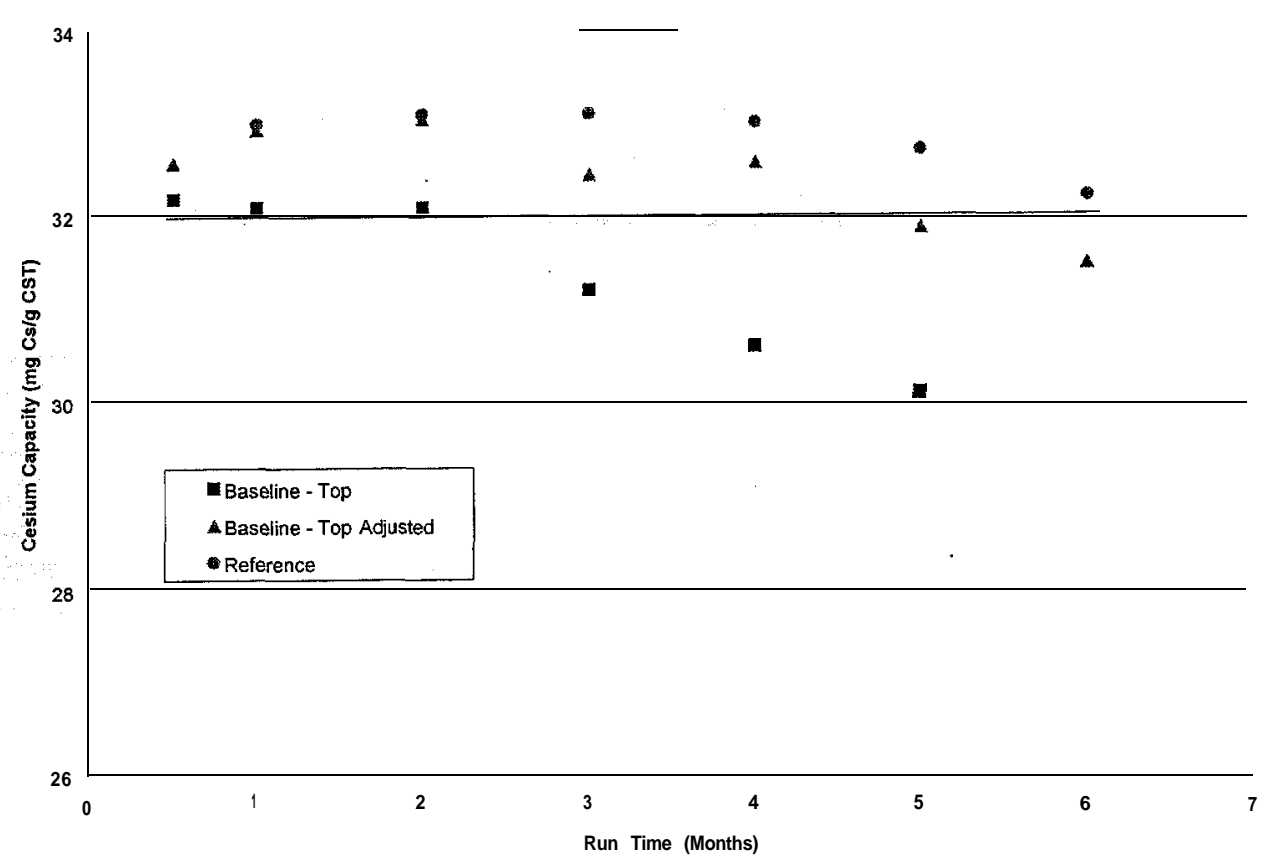

Fig. 7. Measured and adjusted cesium capacity for CST samples, taken from the top of the baseline column.

\subsection{Once-Through Column Test}

The column test using improved (MH-9098-9) CST and SRS average simulant that was pumped once through the column and then discarded was started on February 3, 2001, and ran for 5 months with no operational problems. The simulant for this test was prepared in 100- to 200-L batches, and each batch was stored-for at least 1 month before being used. A small amount of precipitate collected in the bottom of the drum, but the suction line for the pump feeding the column was kept above the settled solids. The measured flow rate of the simulant exiting the column ranged from 1.5 to $2.4 \mathrm{~mL} / \mathrm{min}$, and a total of 430 L (1870 bed volumes) of simulant was used during the test. The pressure drop through the column stayed below 5 psig for the entire test. At the end of the test, the flow rate was increased to $6.0 \mathrm{~mL} / \mathrm{min}$ and the pressure drop increased to $6 \mathrm{psig}$, which is similar to the results that were obtained for the columns using recirculating simulant (described above) when they were operating normally. 
Air bubbles slowly collected in the top portion of the column, and they were removed about once a month by backwashing the column. The flow rate during backwashing was about 5 to $10 \mathrm{~mL} / \mathrm{min}$, which was sufficient to move the air bubbles out of the column but not to fluidize the CST. Samples of CST were collected from the top, middle, and bottom of the column after 1 month and 5 months of operation. For the 1-month samples, the CST moved easily through the sampling valves, but for the 5-month samples, a wire was used to break up the CST before it could be moved through the valves. When the CST was removed from the column at the end of the test, the entire bed was weakly clumped together.

Samples of column effluent and the simulant feed were analyzed periodically. The results for the aluminum concentration in the samples are shown in Fig. 8. Initially the concentration in the effluent was less than that in the feed, indicating that the aluminum was precipitating within the column. For the middle portion of the test, the feed and effluent aluminum concentrations were about the same, and then during the last month of operation, the effluent concentrations were lower, again indicating precipitation of aluminum within the column. No niobium was added to, or detected in, the simulant feed, but the effluent concentration ranged from 4 to $13 \mathrm{mg} / \mathrm{L}$, indicating slight dissolution of niobium from the CST. A total of $2.6 \mathrm{~g}$ of niobium was leached from the $250 \mathrm{~g}$ of CST in the column during the 5 months of operation.

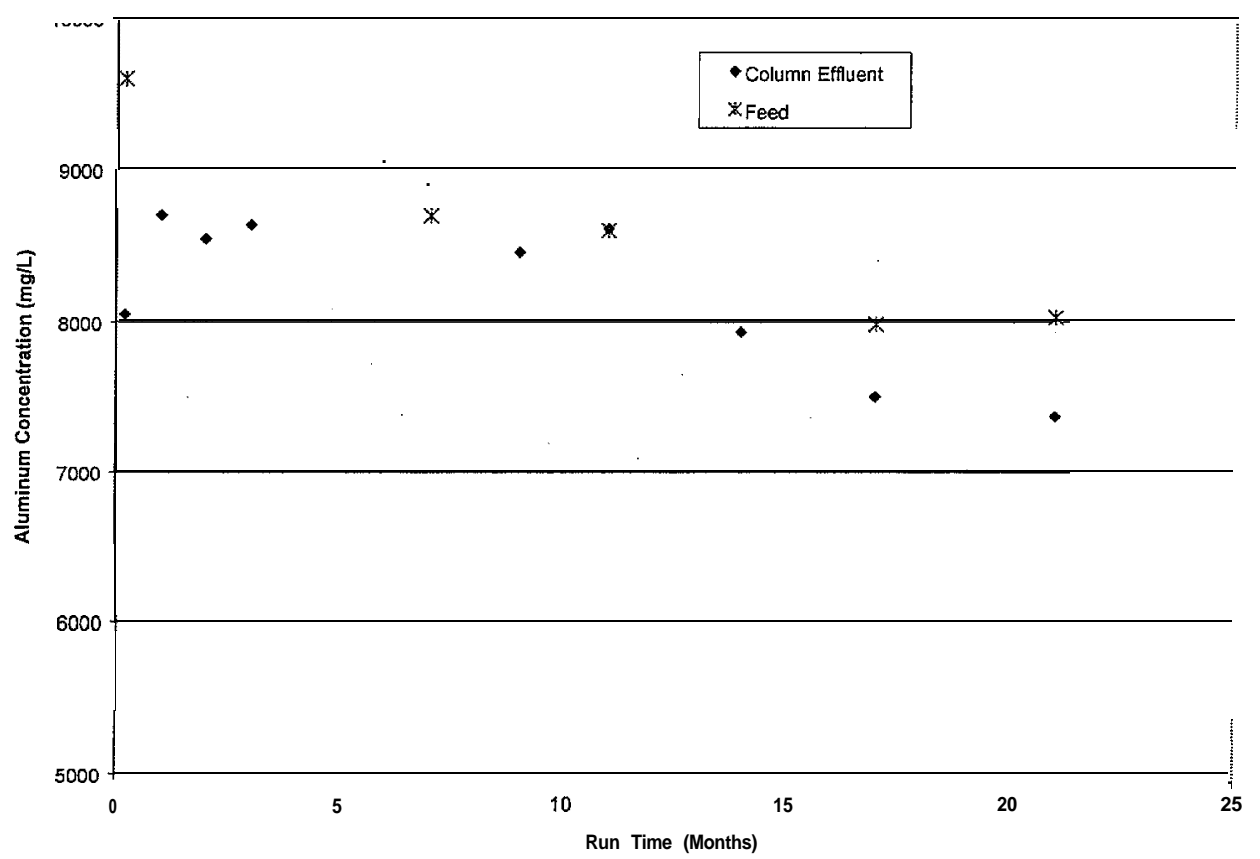

Fig. 8. Aluminum concentrations in feed and effluent samples from the once-through column test using improved (MH-9098-9) CST.

Table 2 provides a summary of the aluminum concentration and the cesium capacity for the CST samples from the once-through column test. The sample taken from the top $1 \mathrm{~cm}$ of the CST bed after 5 months of operation showed a dramatic decrease in cesium capacity and an increase in aluminum concentration. This high aluminum concentration indicates that about $10 \%$ of the CST sample from the top of the column was cancrinite; however, the loss in cesium capacity was significantly larger than what could have been caused by simple dilution of the sample by cancrinite. This effect has been seen in the past with other CST samples that contained significant amounts of cancrinite, and it is likely that the drop in cesium capacity was caused by the cancrinite blocking access to the inner pores of the CST. 
Table 2. Aluminum concentration and measured and adjusted cesium loading capacity for CST samples from the once-through column test

\begin{tabular}{lccc}
\hline $\begin{array}{l}\text { CST sample } \\
\text { description }\end{array}$ & $\begin{array}{c}\text { Aluminum } \\
(\mathrm{mg} / \mathrm{kg})\end{array}$ & $\begin{array}{c}\text { Cesium capacity } \\
(\mathrm{mg} \mathrm{Cs} / \mathrm{g} \mathrm{CST})\end{array}$ & $\begin{array}{c}\text { Adjusted cesium capacity } \\
\text { (mg Cs/g CST) }\end{array}$ \\
\hline Bottom- 1 month & 844 & 31.2 & 31.4 \\
Middle - 1 month & 889 & 30.5 & 30.7 \\
Top - 1 month & 1420 & 30.6 & 30.9 \\
Bottom - 5 month & 1256 & 29.8 & 30.1 \\
Middle - 5 month & 2575 & 29.7 & 30.3 \\
Top - 5 month & 11005 & 10.2 & 11.1 \\
\hline
\end{tabular}

\subsection{Batch Leaching Tests}

The baseline and improved granular CST samples stored at $80^{\circ} \mathrm{C}$ in the average simulant were weakly agglomerated after 1 month of storage. After 2 months of storage, the improved CST sample stored at $50^{\circ} \mathrm{C}$ was also weakly clumped together, and after 3 months, the baseline and improved CST samples stored at $35^{\circ} \mathrm{C}$ had formed clumps. However, the baseline CST sample stored at $50^{\circ} \mathrm{C}$ and both CST samples stored at $23^{\circ} \mathrm{C}$ did not form any clumps. Why the baseline CST stored at $50^{\circ} \mathrm{C}$ responded differently from all of the other CST samples stored at elevated temperatures is not clear. The existing CST clumps did not become any more difficult to break apart as the storage time increased. While monthly samples were being taken, portions of the clumped CST were broken up, and this CST did not re-form into clumps during subsequent storage periods. The samples of CST powder did not form the hard clumps that were observed in the granular CST samples.

Batch tests with production CST samples that were conducted last year formed clumps faster than the samples tested this year. Last year all of the tests conducted at elevated temperatures had formed clumps within the first month, and the samples stored at room temperatures had formed clumps during the second month, The baseline CST was manufactured using the same process as the production samples from last year, but the pretreatment prior to use was slightly different. The production CST samples were pretreated to a $\mathrm{pH}$ of $13(0.1 \mathrm{MNaOH})$ using recirculating sodium hydroxide, and the baseline CST sample was pretreated using $3 \mathrm{M} \mathrm{NaOH}$ in a once-through mode. The higher concentration of sodium hydroxide dissolves more impurities from the CST, and the once-through mode does not allow these impurities to reprecipitate within the bed of CST.

For all of the batch leaching test conditions, the aluminum concentration in the simulants slowly decreased as the aluminum precipitated from the solution. A summary of the results for the three types of CST stored at 25 and $80^{\circ} \mathrm{C}$ is shown in Fig. 9.

Some niobium was leached from the CST samples into the supernate simulant, with higher concentrations measured for the samples stored at lower temperatures. The amount of niobium leached from the CST powder sample at room temperature was much higher than the amount leached from the granular CST samples. The improved CST showed the lowest concentrations. The results for the samples stored at 25 and $80^{\circ} \mathrm{C}$ are shown in Fig. 10. 


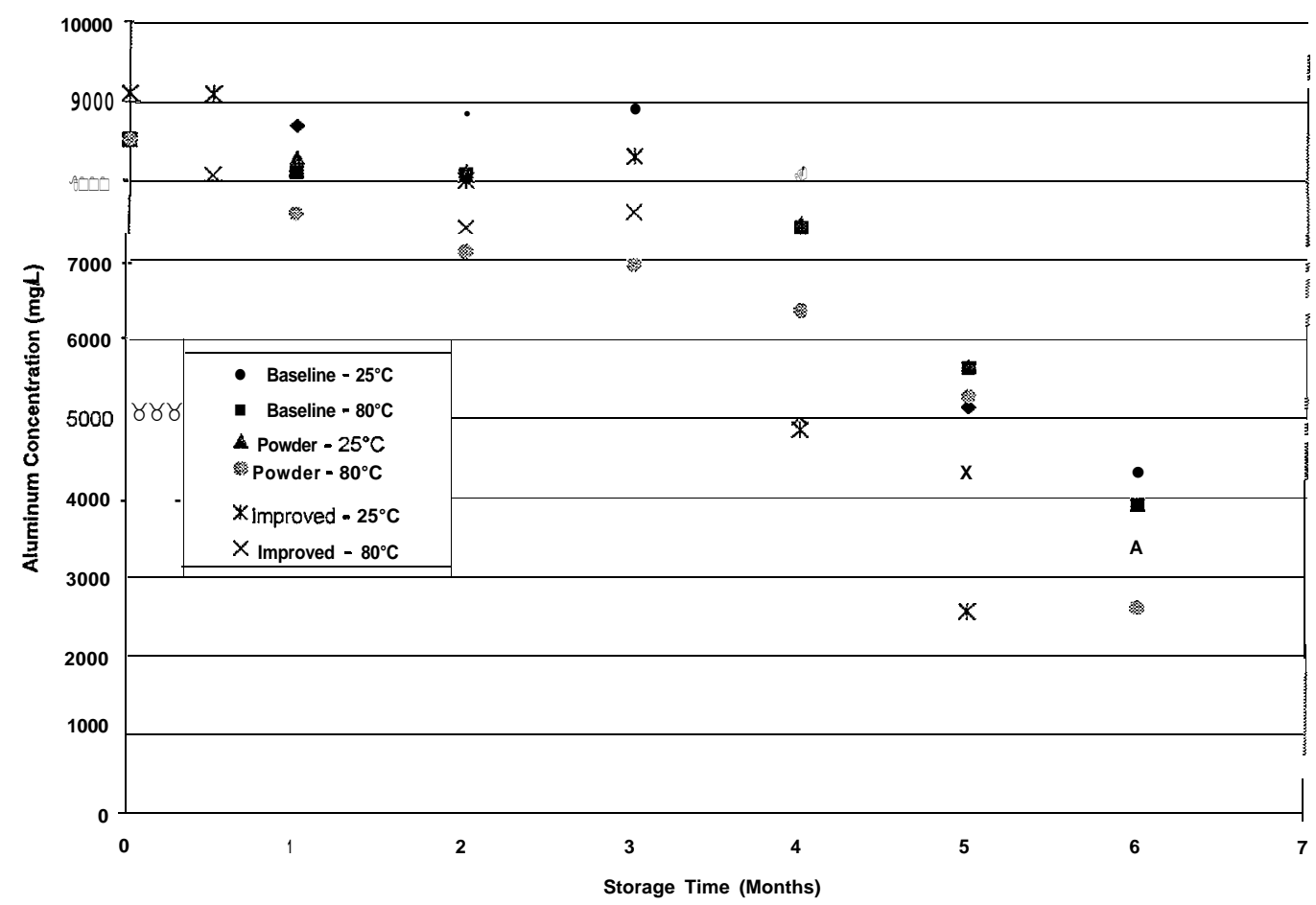

Fig. 9. Aluminum concentration in simulant samples from batch leaching tests using baseline and improved granular CST and CST powder.

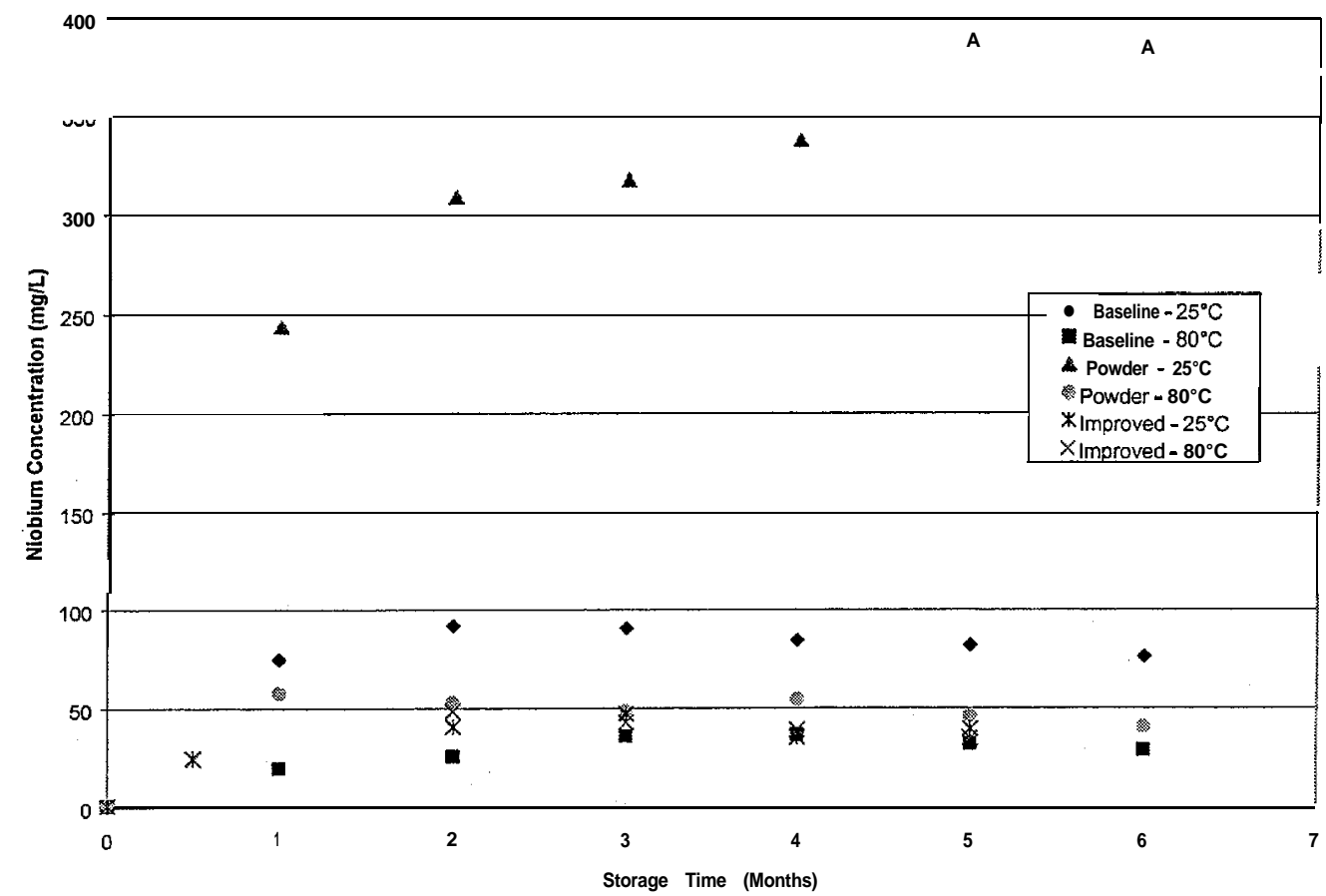

Fig. 10. Niobium concentration in simulant samples from batch leaching tests using baseline and improved granular CST and CST powder. 
The CST in all of the batch tests showed increasing concentrations of aluminum over time, particularly at the higher temperatures. A summary of the results for samples stored at 25 and $80^{\circ} \mathrm{C}$ is provided in Fig. 11. No other metal contaminants were detected at significant concentrations in the samples of CST, and the concentrations of the CST components $(\mathrm{Na}, \mathrm{Si}, \mathrm{Ti}, \mathrm{Zr}$ and $\mathrm{Nb}$ ) decreased very slightly as the aluminum concentration increased. The measured concentrations of silicon showed much more scatter than was observed for the other elements, and this same effect was seen for the samples analyzed last year. The difference seems to have been caused by the sample preparation (digestion and dilution) process, since there was less variation within each group of samples that were prepared at the same time, as compared with groups of samples prepared at different times. Fluorine from the hydrofluoric acid used in the digestion process can form volatile compounds with silicon, which could evaporate from the solubilized CST.

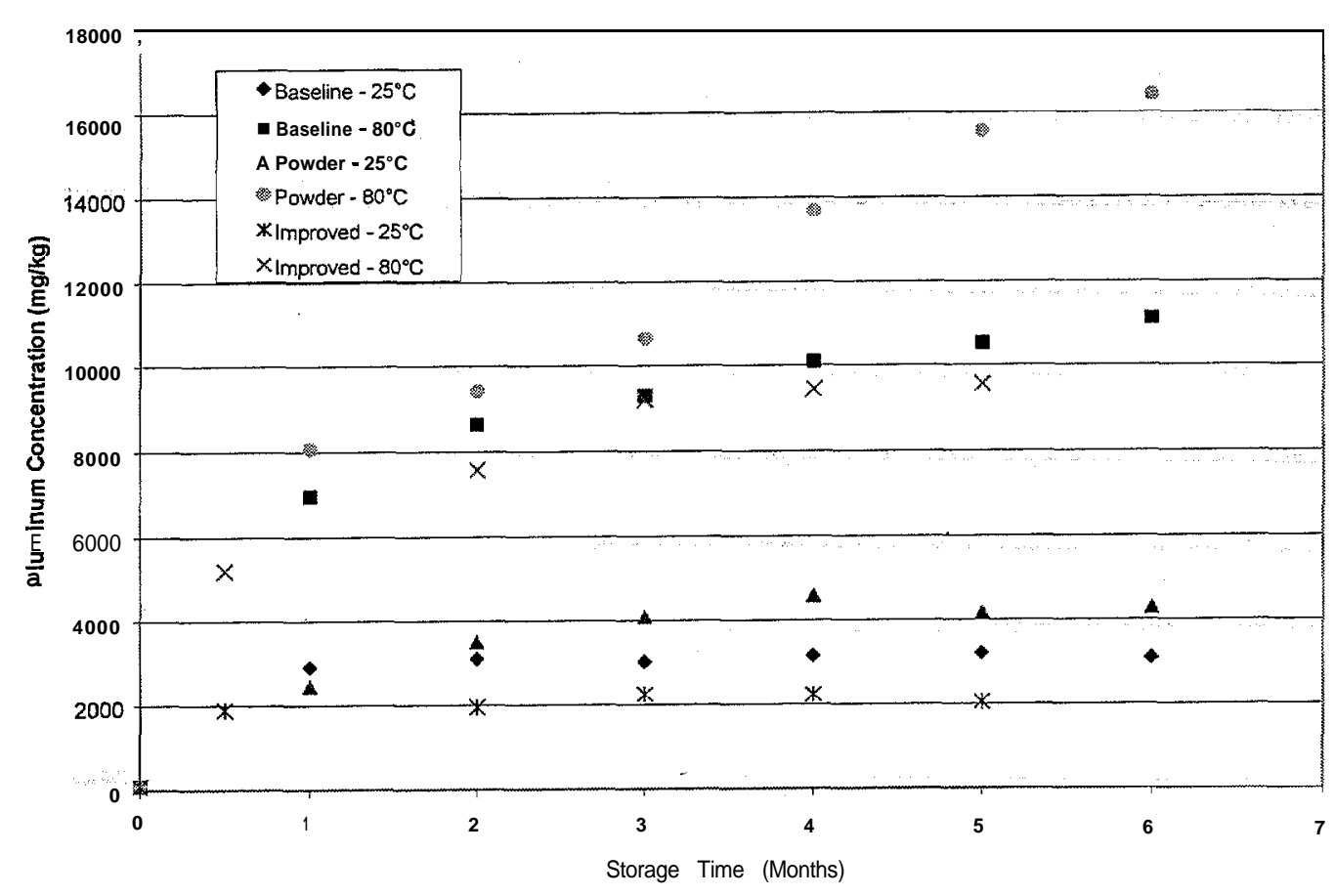

Fig. 11. Aluminum concentration in CST samples from batch leaching tests using baseline and improved granular CST and CST powder.

Storage temperature had a strong effect on the cesium capacity of the CST samples from the batch leaching tests, with a drop of about $15 \%$ for samples stored at $80^{\circ} \mathrm{C}$ compared with samples stored at $23{ }^{\circ} \mathrm{C}$ (Table 3). The cesium capacity of the baseline and improved CST samples was almost the same. The CST powder showed a higher capacity because it lacks the zirconia binder that dilutes the CST in the granular samples. The samples stored at $23^{\circ} \mathrm{C}$ showed a very small decrease in cesium capacity as the storage time in the simulant increased up to 6 months (Fig. 12), whereas the samples stored at $80^{\circ} \mathrm{C}$ showed a slow, steady decrease in cesium capacity (Fig. 13). The results of the cesium loading tests on the reference samples (unused baseline CST) were very consistent, with a very slight decrease for the 5- and 6-month samples, which indicated that the loading tests were reproducible. Figure 13 also shows the results for an adjusted cesium capacity that was calculated by eliminating the weight of cancrinite from the measured sample weights. The amount of cancrinite was calculated from the measured 
concentrations of aluminum and titanium in each CST sample. The weight of cancrinite could not account for the total drop in cesium capacity, thus indicating that another mechanism, such as blocking access to the CST pores, was also involved in the loss of cesium capacity. Samples of production batches of CST tested last year showed faster losses in cesium capacity, with drops of 18 to $20 \%$ for samples stored at $80^{\circ} \mathrm{C}$ for 2 months and longer.

Table 3. Average cesium loading capacities for CST samples stored at 23 and $80^{\circ} \mathrm{C}$ for up to 6 months ${ }^{a}$

\begin{tabular}{llccc}
\hline \multicolumn{2}{c}{ CST } & \multicolumn{2}{c}{ Cesium capacity $(\mathrm{mg}$ Cs/g CST) \pm S.D. } & \\
\cline { 1 - 3 } ID no. & Description & Stored at $23^{\circ} \mathrm{C}$ & Stored at $80^{\circ} \mathrm{C}$ & Change $(\%)$ \\
\hline 9090-76 & Baseline & $31.5 \pm 0.28$ & $26.6 \pm 1.0$ & 15.5 \\
$30950-48$ & Powder & $36.1 \pm 0.34$ & $30.6 \pm 2.0$ & 15.2 \\
MH-9098-9 & Improved & $31.6 \pm 0.53$ & $26.8 \pm 1.5$ & 15.2 \\
\hline
\end{tabular}

"All of the cesium loading tests were performed at $23^{\circ} \mathrm{C}$ using average simulant that initially contained $50 \mathrm{mg} / \mathrm{L}$ cesium.

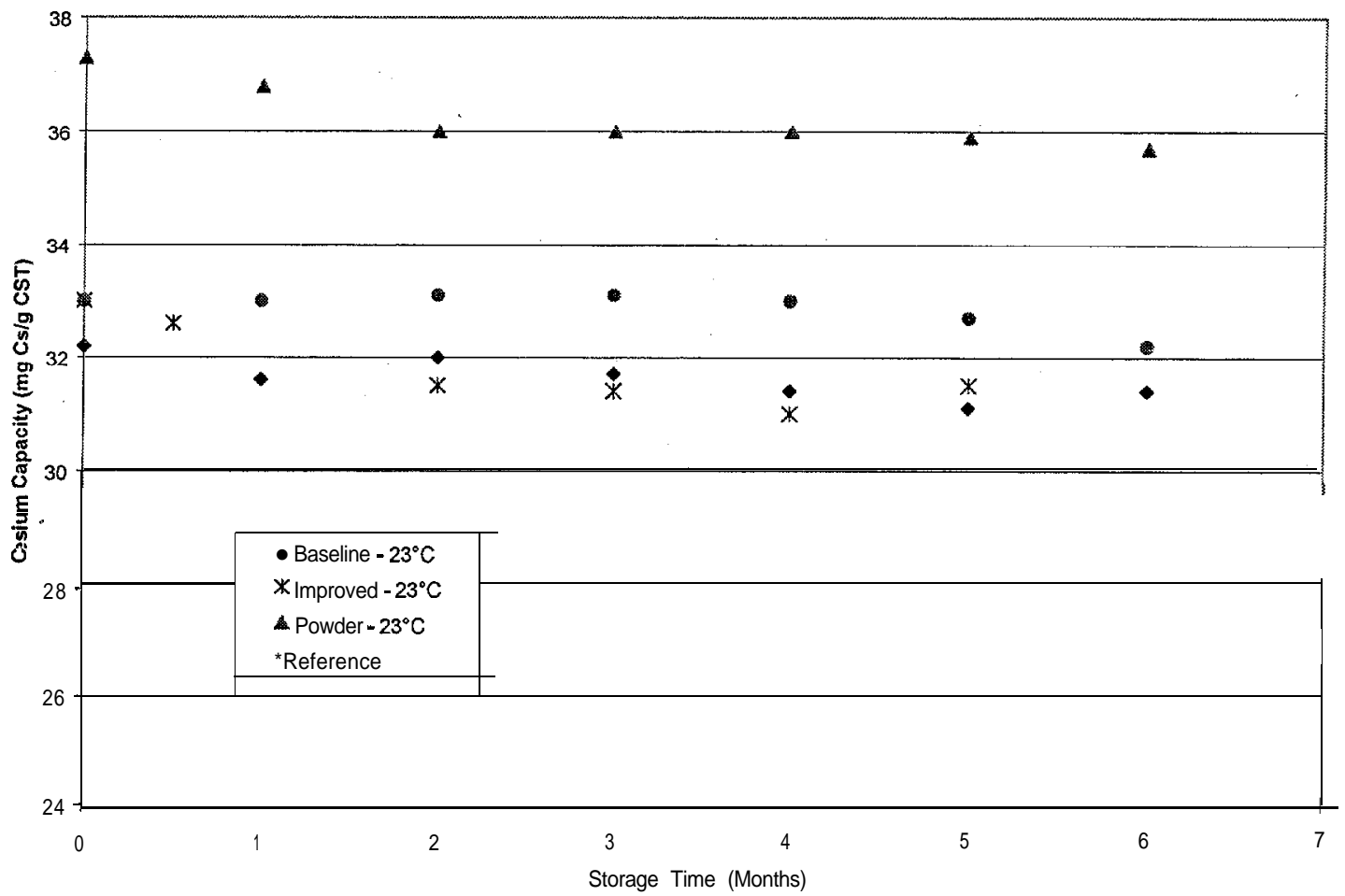

Fig. 12. Results of cesium loading tests for CST samples from batch leaching tests stored in SRS average simulant at $23^{\circ} \mathrm{C}$. 


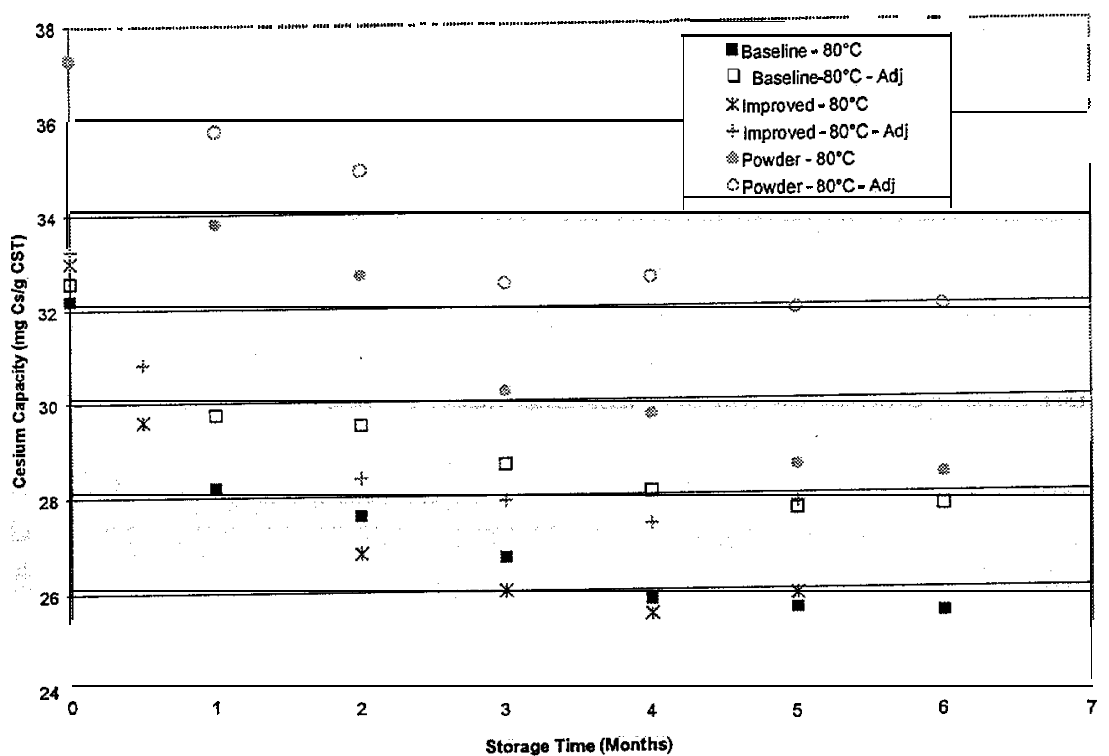

Fig. 13. Results of cesium loading tests for CST samples from batch leaching tests stored in SRS average simulant at $80^{\circ} \mathrm{C}$. The adjusted capacities were calculated by eliminating the weight of cancrinite in each sample.

Figure 14 shows the cesium capacity results for all of the samples after 4 months of storage in the average simulant. These results are typical of those observed for other storage times. (Note: All of the cesium loading tests were performed at room temperature.) There was a slight drop in capacity as the storage temperature increased, from 23 to $35^{\circ} \mathrm{C}$, and then a more pronounced drop as the storage temperature increased to $50^{\circ} \mathrm{C}$ and then $80^{\circ} \mathrm{C}$.

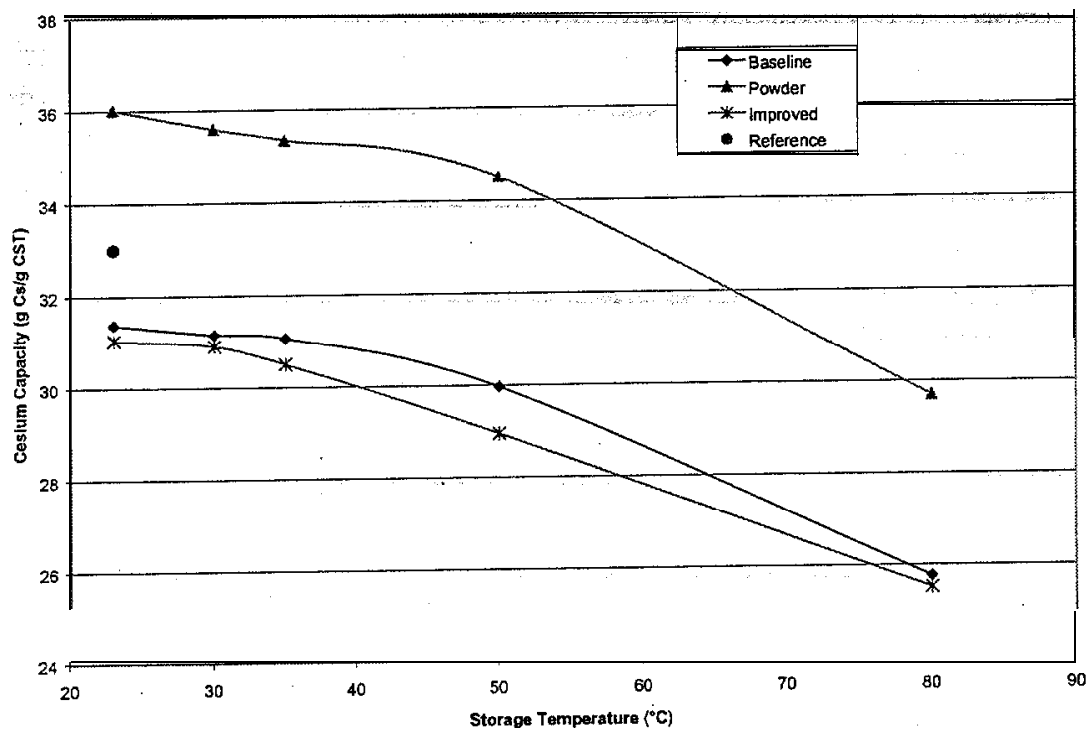

Fig. 14. Results of cesium loading tests for CST samples after 4 months of storage in SRS average simulant. 


\section{CONCLUSIONS}

Experimental determination of the chemical stability of baseline and improved granular CST and the CST powder used to make both granular samples has been completed. The work was performed to evaluate the long-term chemical stability of these CST samples when exposed to supernate simulant using a range of possible operating conditions and temperatures and to compare the results to similar tests performed last year on production samples of CST.

The column tests using recirculating simulant showed that the baseline CST generated more precipitates of sodium aluminosilicate than the improved CST. The precipitates were particularly evident in the tubing that carried the simulant solution to and from the column, but the baseline CST also showed higher concentrations of aluminum on the CST than was observed for the improved CST. The sodium aluminosilicate formed bridges between the CST granules, causing clumps of CST to form in the column. Clumps were visible in the baseline CST column after 1 month of operation and in the improved CST column after 2 months. For the baseline CST column, the clumps were routinely dispersed by backwashing the column with simulant. After 96 days of operation, a thin hard layer of CST formed on the bottom screen of the baseline column that restricted flow through the column. The bottom cap was removed and the CST was scraped from the screen to restore the column to normal operation. After 3 months of operation, the improved CST column had completely clumped together and could not be dispersed by backwashing. The pressure drop through the column was still relatively low, so the test was continued until the pressure drop increased to $>15$ psig, which occurred after 105 days of operation. The column was then disassembled, and the CST was physically removed from the column and broken up. These results show that when in contact with the supernate simulant, both the baseline and improved CST have the potential to form clumps that can restrict the flow through the small columns used in these tests.

The cesium capacity of the CST samples from the column test decreased slightly as the run time increased. Most of this decrease was caused by the weight of cancrinite (a sodium aluminosilicate) on the CST samples. Tests conducted last year using samples of production batches of CST showed a more pronounced drop in cesium capacity under comparable conditions.

The column test with improved CST and once-through simulant showed few problems during the 5 months of operation. The pressure drop through the column remained low; however, the CST in the column had clumped together by the time the final samples were taken after 5 months. The final sample taken from the top of the column showed a 65\% drop in cesium capacity as compared with all the other samples taken from this column. This sample also contained the highest concentration of cancrinite, but the weight of cancrinite could account for only a small fraction of the drop in cesium capacity by simple dilution of the CST. An additional mechanism is involved in the drop in cesium capacity, probably blocking access to the pores of the CST particles by the cancrinite.

The CST in the batch tests stored at elevated temperatures in average simulant formed clumps, but this occurred at a slower rate than that observed last year during comparable tests using production batch samples of CST. Storage at elevated temperatures caused a gradual decrease in cesium capacity as the storage time increased, with a loss in capacity of up to $20 \%$ after 5 to 6 months at $80^{\circ} \mathrm{C}$. The results for the baseline and improved CST samples were essentially the same for the batch tests. 


\section{REFERENCES}

1. P. A. Taylor and C. H. Mattus, Thermal and Chemical Stability of Crystalline Silicotitanate Sorbent, ORNL/TM-1999/233, Oak Ridge National Laboratory, Oak Ridge TN, October 1999.

2. P. A. Taylor and C. H. Mattus, Thermal and Chemical Stability of Crystalline Silicotitanate Sorbent, ORNL/TM-2000/307, Oak Ridge National Laboratory, Oak Ridge, TN, May 2001.

3. W. R. Wilmarth, V. H. Dukes, J. T. Mills, and F. F. Fondeur, Effect of Sodium Hydroxide Pretreatment of UOP IONSIV® IE-91 I Crystalline Silicotitanate Sorbent, WSRC-TR-2000-00167, Westinghouse Savannah River Company, Aiken, SC, April 2000.

4. J. L. Krumhansl, P. C. Zhang, C. Jove-Colon, H. L. Anderson, R. C. Moore, F. M. Salas, T. M. Nenoff, and D. A. Lucero, A Preliminary Assessment of IE-911 Column Pretreatment Options, SAND2001-1002, Sandia National Laboratories, Albuquerque, NM, April 2001.

5. Y. Su, L. Li, J. S. Young, and M. L. Balmer, Investigation of Chemical and Thermal Stabilities of Cs-Loaded UOP IONSI ${ }^{\circledR}$ IE-91 I Ion Exchanger (Final Report), PNNL-13392-2, Pacific Northwest National Laboratory, Richland, WA, March 2001.

6. D. D. Walker, Preparation of Simulated Waste Solutions, WSRC-TR-99-00116, Rev. 0, Westinghouse Savannah River Company, Aiken, SC, April 1999.

7. M. D. Nyman, T. J. Headley, T. M. Nenoff, and L. D. Bustard, Performance of IE-911: Characterization of As-Received, NaOH-treated and Simulant-treated CST, SAND2001-0435P, Sandia National Laboratories, Albuquerque, NM, February 2001. 



\section{INTERNAL DISTRIBUTION \\ T.}

1. J. L. Collins

2. J. N. Herndon

3. R. T. Jubin'

4. D. D. Lee

5. B. E. Lewis

6. C. H. Mattus

7. C. P. McGinnis

\author{
8. S. M. Robinson \\ 9-12. P. A. Taylor \\ 13. J. F. Walker \\ 14. ORNL Central Research Library \\ 15. ORNL Laboratory Records-RC \\ 16. ORNL Laboratory Records-OSTI
}

\section{EXTERNAL DISTRIBUTION}

17. L. Balmer, Pacific Northwest National Laboratory, 902 Battelle Blvd., Richland, WA 99352

18 L. D. Bustard, Sandia National Laboratories, P.O. Box 5800, MS: 0728, Albuquerque, NM 87185-5800

19. J. T. Carter, Westinghouse Savannah River Company, Bldg. 704-3N, Room: S15 1, Aiken, SC 29808

20. E. J. Cruz, U.S. Department of Energy, P.O. Box 550, MSIN: H6-60, Richland, WA 99352

21. F. Damerow, West Valley Nuclear Services, P.O. Box 191, West Valley, NY 14171

22. I. L. Drake, Jr., U.S. Department of Energy, 10282 Rock Springs Road, West Valley, NY 14171

23. D. Fennelly, UOP LLC, 307 Fellowship Road, Suite 207, Mt. Laurel, NJ 08054

24. S. D. Fink, Westinghouse Savannah River Company, P.O. Box 616,773-A, Room B112, Aiken, SC 29808

25. Tanks Focus Area Headquarters Program Lead, c/o Kurt Gerdes, DOE Office of Science and Technology, 19901 Germantown Rd., 1154 Cloverleaf Bldg., Germantown, MD 20874-1290

26. P. W. Gibbons, Numtec Hanford Corporation, P.O. Box 999, MS: K9-91, Richland, WA 99352

27. R. L. Gilchrist, Pacific Northwest National Laboratory, P.O. Box 999, MS: K9-91, Richland, WA $9 \begin{array}{lllll} & 3 & 5 & 2\end{array}$

28. T. S. Gutmann, U.S. Department of Energy, Savannah River Operations Office, P.O. Box A, Aiken, SC 29802

29. H. D. Harmon, Tanks Focus Area at Savannah River, Bldg. 704-3N, Room ${ }^{N 1} 11$, Aiken, SC 29808

30. R. N. Hinds, Westinghouse Savannah River Company, Bldg. 704-3N, Room S162, Aiken, SC 29808

31. E. W. Holtzscheiter, Westinghouse Savannah River Company, Savannah River Technology Center, Building 773-A, Room A-229, MS: 28, Aiken, SC 29808

32. J. 0. Honeyman, CH2M Hill (CHG), P.O. Box 1500, MS: H6-62, Richland, WA 99352

33. R. T. Jones, Westinghouse Savannah River Company, Bldg. 704-3N, Room: S122, Aiken, SC 29808

34. J. Krumhansl, Sandia National Laboratories, P.O. Box 5800, MS: 0750, Albuquerque, NM 87185-0750

35. L. Li, Pacific Northwest National Laboratory, 902 Battelle Blvd., Richland, WA 99352

36. K. A. Lockie, U.S. Department of Energy, Idaho Operations Office, 750 DOE Place, MS: 1145, Idaho Falls, ID 83402

37. J. W. McCullough, Jr., DOE at Savannah River, Bldg. 704-3N, Room S101, Aiken, SC 29808 
38. J. P. Morin, Westinghouse Savannah River Company, Savannah River Technology Center, Bldg. 703-H, Room: 119, Aiken, SC 29808

39. J. R. Noble-Dial, U.S. Department of Energy, Oak Ridge Operations Office, P.O. Box 2001, Oak Ridge, TN 37830-8620

40. A. Olson, Idaho National Engineering and Environmental Laboratory, Bldg. 637, MS-521 8, Idaho Falls, ID 83415-5218

41. L. M. Papouchado, Westinghouse Savannah River Company, P.O. Box 616,773-A, Room A263, Aiken, SC 29808

42. S. F. Piccolo, Westinghouse Savannah River Company, Bldg. 704-3N, Room: S 152, Aiken, SC 29808

43. Tanks Focus Area Program Manager, c/o T. P. Pietrok, U.S. Department of Energy, Richland Operations Office, P.O. Box 550, MS: K8-50, Richland, WA 99352

44, J. A. Pike, Westinghouse Savannah River Company, Bldg. 704-19@N, Room: N401, Aiken, SC 29808

45. J. M. Reynolds, U.S. Department of Energy, Savannah River Operations Office, Bldg. 704-196N, Room: S441, Aiken, SC 29808

46. L. Roeder-Smith, TFA Communications, Pacific Northwest National Laboratory, P.O. Box 999, MSIN K9-69, Richland, WA 99352

47. S. N. Schlahta, TFA Salt Waste Processing Program, Westinghouse Savannah River Company, Bldg. 704-3N, Room: N121, Aiken, SC 29808

48. W. W. Schulz, 12704 Sandia Ridge Place NE, Albuquerque, NM 87111

49. Y. Su, Pacific Northwest National Laboratory, 902 Battelle Blvd., Richland, WA 99352

50. P. C. Suggs, DOE-AMHLW/SPPD, Bldg. 704-3N, Aiken, SC 29808

51. W. L. Tamosaitis, Westinghouse Savannah River Company, P.O. Box 616,773-A, Room A23 1, Aiken, SC 29808

52. L. Tavlarides, Syracuse University, Dept. of Chemical Engineering and Materials Science, 334 Hinds Hall, Syracuse, NR 13244-1190

53. M. T. Terry, Los Alamos National Laboratory, P.O. Box 999, MSIN K9-9 1, Richland, WA 99352

54. T. R. Thomas, Lockheed Martin Idaho Technologies Company, P.O. Box 1625, MSIN 3458, Idaho Falls, ID 83415-3423

55. T. A. Todd, Idaho National Engineering and Environmental Laboratory, Bldg. 637, MS: 5218, Idaho Falls, ID 83415-5218

56. J. H. Valentine, Lockheed Martin Idaho Technologies Company, P.O. Box 1625, MS: 3204, Idaho Falls, ID 83415-3204

57. G. Vandegrift, Argonne National Laboratory, Bldg. 205, 9700 South Cass Avenue, Argonne, IL 60439

58. D. D. Walker, Westinghouse Savannah River Company, P.O. Box 616,773-A, Room B124, Aiken, SC 29808

59. D. W. Wester, TFA System Lead, Pacific Northwest National Laboratory, 902 Battelle Boulevard, P.O. Box 999/MS P7-25, Richland, WA 99352

60. W. R. Wilmarth, Westinghouse Savannah River Company, P.O. Box 616, 773-42A, Room 153, Aiken, SC 29808

61. Tanks Focus Area Technical Team c/o B. J. Williams, Pacific Northwest National Laboratory, P.O. Box 999, MSIN K9-69, Richland, WA 99352 


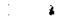


